\title{
EVIDENCE ON CLIMATIC VARIABILITY AND PREHISTORIC HUMAN ACTIVITIES BETWEEN 165 B.C. AND A.D. 1400 DERIVED FROM SUBFOSSIL SCOTS PINES (PINUS SYLVESTRIS L.) FOUND IN A LAKE IN UTSJOKI, NORTHERMOST FINLAND
}

\author{
PENTTI ZETTERBERG, MATTI ERONEN \\ and KEITH R. BRIFFA
}

\begin{abstract}
ZETTERBERG, PENTTI; ERONEN, MATTI and BRIFFA, KEITH, R., 1994: Evidence on climatic variability and prehistoric human activities between 165 B.C. and A.D. 1400 derived from subfossil Scots pines (Pinus sylvestris L.) found in a lake in Utsjoki, northernmost Finland. Bull. Geol. Soc. Finland 66, Part 2, 107-124.

Samples from 1265 subfossil pines have been collected from small lakes and peat deposits in the forest-limit zone of northern Fennoscandia in order to study past variations of climate. Many of the subfossils have been dated by dendrochronology and the chronology constructed from the measured ring-width data extends as a continuous master curve from the present back until 165 B.C. and after a short gap until about 7000 years before the present time. This material has greatly increased the number of dated pine megafossils in northern Finland which had previously been restricted only to radiocarbon-dated samples. In addition to the year-by-year information provided by tree-ring width data, the temporal distribution of pine megafossils found in the vicinity of the forest-limit zone also provides information on past climatic changes.

The 102 pine subfossils collected from Lake Ailigas, in Utsjoki, form part of the above material. They provide information about past variations in pine growth caused, to a large degree, by changing climate at this one site, but they also give glimpses of the local activities of Prehistoric Man. The data from 90 of these trees have been successfully dated using dendrochronological techniques and the results show that all of them grew during the time period beginning 3000 years before present, and that 79 pines lived during the time span 165 B.C. to A.D. 1952. In several lakes in the forest-limit zone, some subfossil trees are much older than those in Lake Ailigas. The relatively young ages of the subfossils at this site indicates that the lake has been in existence probably only during the past 3000 years, forming when climate turned more humid than in earlier times.

The present continuous master curve is about 600 years longer than the earlier published pine chronology for northern Sweden, though this has recently been extended to A.D. 1. In the present study, the life spans of individual dated pines are considered in conjunction with the variability in the measured tree-growth curve. These provide detailed information on growth conditions and variations in temperature during the period 165 B.C. - A.D. 1400. The correlation of the present data with the previously published results from northern Sweden display great general similarity, but also some significant differences. We propose that the combined data give a more reliable indication of regional climatic variations
\end{abstract}


and that the differences are due to local factors at the two locations. The similarity between these two independent series supports general conclusions made about changing summer climate over Fennoscandia after A.D. 500 and strongly suggests that our conclusions drawn here for the period 165 B.C. - A.D. 500 are on a firm basis. The present data thus enable us to infer the record of summer climate variability in northern Fennoscandia about 600 years back in time.

Most of the subfossil pines preserved in the lake grew very close to the place where they were found. Reaction wood indicating tilting of the trunk, probably caused by rising water levels, was found in several trees. These trees grew on the lake shore where the soil was soft or eroding. The large number of relatively young trees indicates that storms may have occasionally felled pines. This cannot be proven (by demonstrating a common death year) however, because the outermost tree rings in the subfossil material are frequently decayed. A small number of the pines found in Lake Ailigas were cut by Man. The pines, identified by axe marks may be remnants of barriers built by the Prehistoric Saami for hunting of wild reindeer. The dates of these indicate that traps were constructed in the mid 9th century and at the end of the 11th and start of the 12th centuries, i.e. late Iron Age times.

Key words: dendrochronology, subfossil tree, Scots pine (Pinus sylvestris L.), tree limit, forest history, lake-levels, climate change, Saami Iron Age, Late Holocene, Lapland, Finland

Pentti Zetterberg: University of Joensuu, Karelian Institute, Section of Ecology, P.O. Box 111, FIN-80101 Joensuu, Finland

Matti Eronen: University of Oulu, Department of Geology, Linnanmaa, FIN-90570 Oulu, Finland

KeithR. Briffa: Climatic Research Unit, University of East Anglia, GB-Norwich NR4 $7 T J$

\section{INTRODUCTION}

Samples from 1265 subfossil pines preserved in small lakes and peat bogs in the forestlimit zone of northernmost Finland and adjacent areas in Norway had been collected by summer 1994. In order to study variations in past climate (Eronen and Zetterberg 1992), this material has been subjected to dendrochronological analysis, which had yielded a long annual time series of mean ring-width. The chronology extends back in time almost 7000 years, only interrupted by a gap of ca. 250 years before 165 B.C. (Zetterberg and Eronen 1994).

The material has been collected from a broad zone running along the polar/alpine pine forest limits in northern Fennoscandia. The samples thus comprise data from different parts of that ecotone. The variations in tree-ring width are, however, very similar within this area, because the control of annual growth by environmental factors, particularly climate, is strong and clearly discernible in areas where trees grow in marginal environments (Fritts 1976). This makes it relatively easy to correlate the chronologies from different sites. In spite of this large-scale homogeneity in the interannual growth of forest-limit pines, there are slight regional differences in tree-ring series which are due to local differences in climatic conditions between the 
western and the eastern parts of northern Fennoscandia. We can consider the entire data set of northern Fennoscandian trees as one general source of large-scale information but we can also view the different site and regional chronologies separately to study the regional differences (Zetterberg 1987, Lindholm et al. in press). The comparison of data from different sites will identify common changes in tree growth which represent important evidence of large-regionally representative past climatic changes, and regional differences which we may interpret as local climate variability.

Past locations of the pine subfossils in relation to the present limit of pine are also indicative of past climate. Logs, several thousands years old, have been found even tens of kilometres beyond the present limit of pine, and at altitudes above the highest present occurrences of pine trees. Eronen (1979) surveyed earlier studies on the distribution of subfossil pines in Finnish Lapland. These, together with pollen studies, show that the maximum extension of pine in Finnish Lapland occurred during mid-Holocene time (6000 - 4000 B.P.) (Eronen and Huttunen 1987, Eronen and Zetterberg in press). Similarly, the analyses of pine ring-width variations during the mid-Holocene indicate that a marked change in climate took place in northern Fennoscandia about 5000 B.P. Climatic conditions became more unstable, which led to a gradual deterioration of climate (Zetterberg et al. in press). As a consequence of this change, the pine limit retreated during the latter part of the Holocene. The Finnish data indicate that the retreat of pine forest was a gradual process, when viewed over the whole area of Lapland (Eronen and Zetterberg in press).

Samples of subfossil pines have been collected from 38 sites, mostly small lakes. A small minority of the samples were collected from peat sections. The subaquatic samples were collected with the help of a diver who recovered all logs found. However, not all were sampled. Badly decayed trunks, stumps with only the base of the trunk preserved, and young tree containing only a few tens (below 50) of annual rings were rejected as unsuitable for dendrochronological studies.
Many individual lakes yielded several tens of subfossil logs. Over 100 pine trunks were collected from five small lakes and a total of 219 subfossil pine trees were sampled at one site in Enontekiö, western Finnish Lapland. The abundance of subfossil pines makes it possible to explore the long-term stand history of pine in one location over thousands of years.

The traditional approach to the palaeoclimatological interpretation of old trees is to develop long series of averaged ring-width or standardised ring indices (chronologies) and to reconstruct palaeotemperatures using regression equations calibrated against modern instrumental records. In Finnish Lapland, it has been convincingly demonstrated that the growth of tree-limit pines is highly correlated with interannual variability of summer temperatures (Hustich 1948, Mikola 1950). Later investigations in northern Fennoscandia have confirmed and exploited this knowledge through the reconstruction of past summer temperature averages for hundreds and even thousands of years (Aniol and Eckstein 1984, Briffa et al. 1988, 1990, 1992). All of these interpretations are based on the principle of uniformitarianism. i.e., on the assumption that the environmental/climatic signal represented in the tree-ring time series has not changed over time. However, it is difficult in practice to demonstrate this. In this paper we consider complementary sources of palaeoclimatic information derived from these trees that can be compared with the variability within a new long site chronology that extends back beyond the beginning of the Christian era.

\section{MATERIAL AND METHODS}

The sampling site for this study was Lake Ailigas, which is situated near the main village of the Utsjoki commune, and near Tana River and fell Ailigastunturi $\left(69^{\circ} 54^{\prime} \mathrm{N}, 27^{\circ} 04^{\prime} \mathrm{E}, 75 \mathrm{~m}\right.$ above sea level) (Fig. 1). The lake itself is narrow, less than 50 $\mathrm{m}$ wide, about $750 \mathrm{~m}$ long and shallow. The lake basin was probably formed by running water during 


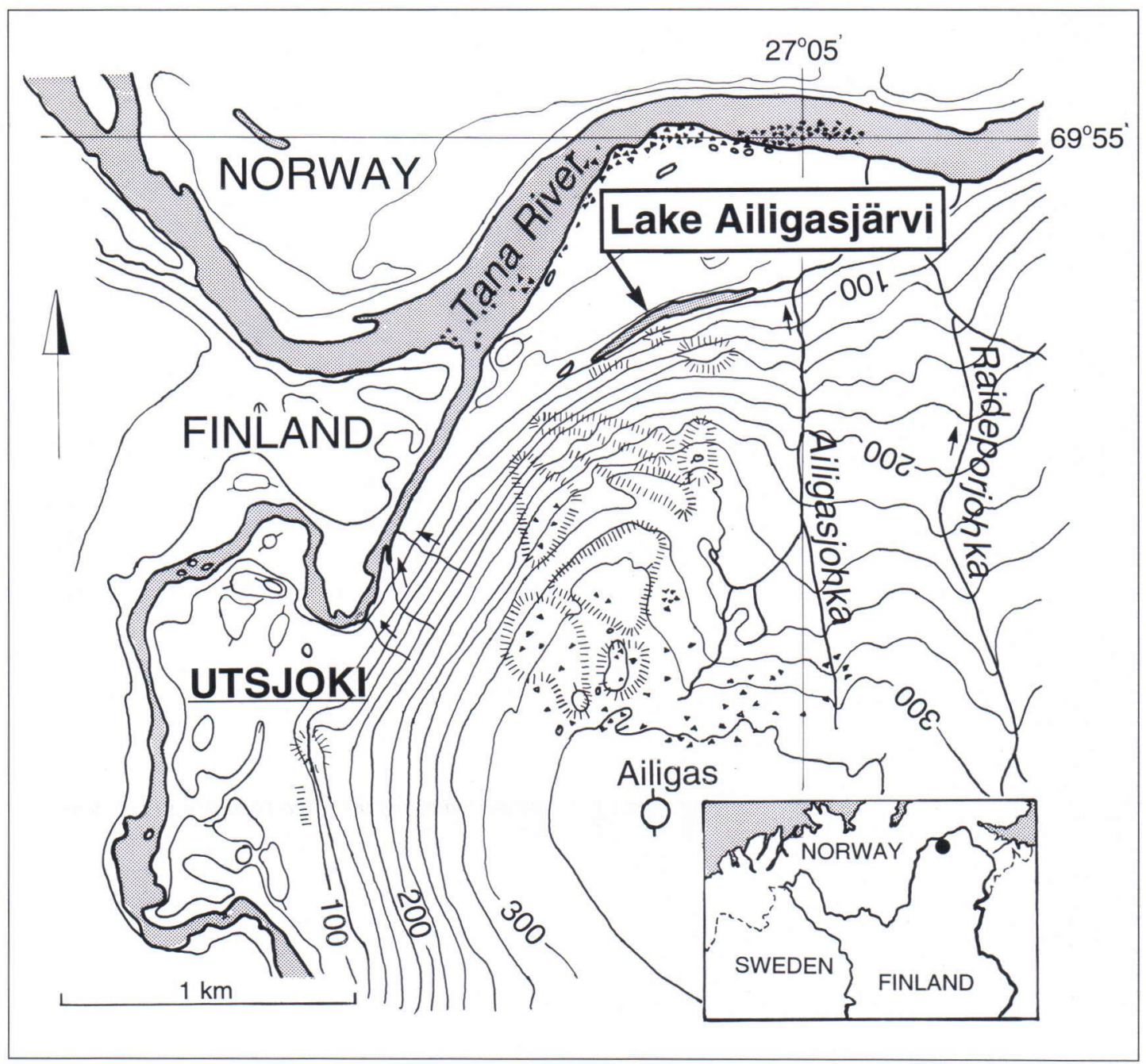

Fig. 1. Map of Lake Ailigas (Ailigasjärvi) and its surroundings in Utsjoki, northernmost Finland.

the deglaciation, or soon after, in early Holocene time. The dominant tree species in the area is mountain birch (Betula pubescens, ssp. czerepanovii). Today, there are no pines growing in the vicinity of the lake. Pine forests are common in the valleys of the Tana and Utsjoki Rivers upstream (southwards) from the sampling site. Both ends of Lake Ailigas are paludified. Its bottom is muddy and edges mostly covered by peat, but the side towards the slope of Ailigastunturi is rich in boulders and stones (Fig. 2).
A total of 102 samples of subfossil pines were collected during the 1992 field season. Observations made during sample collection revealed that a number of the pines had originally been cut by axe. These findings are described in a separate paper (Eronen et al. 1994b), but are also discussed here later.

Sample discs were cut by chainsaw about $1-1.5$ $m$ above the original root plate, whenever possible. Often the lower part of tree was not preserved and in those cases the samples were cut higher up from 

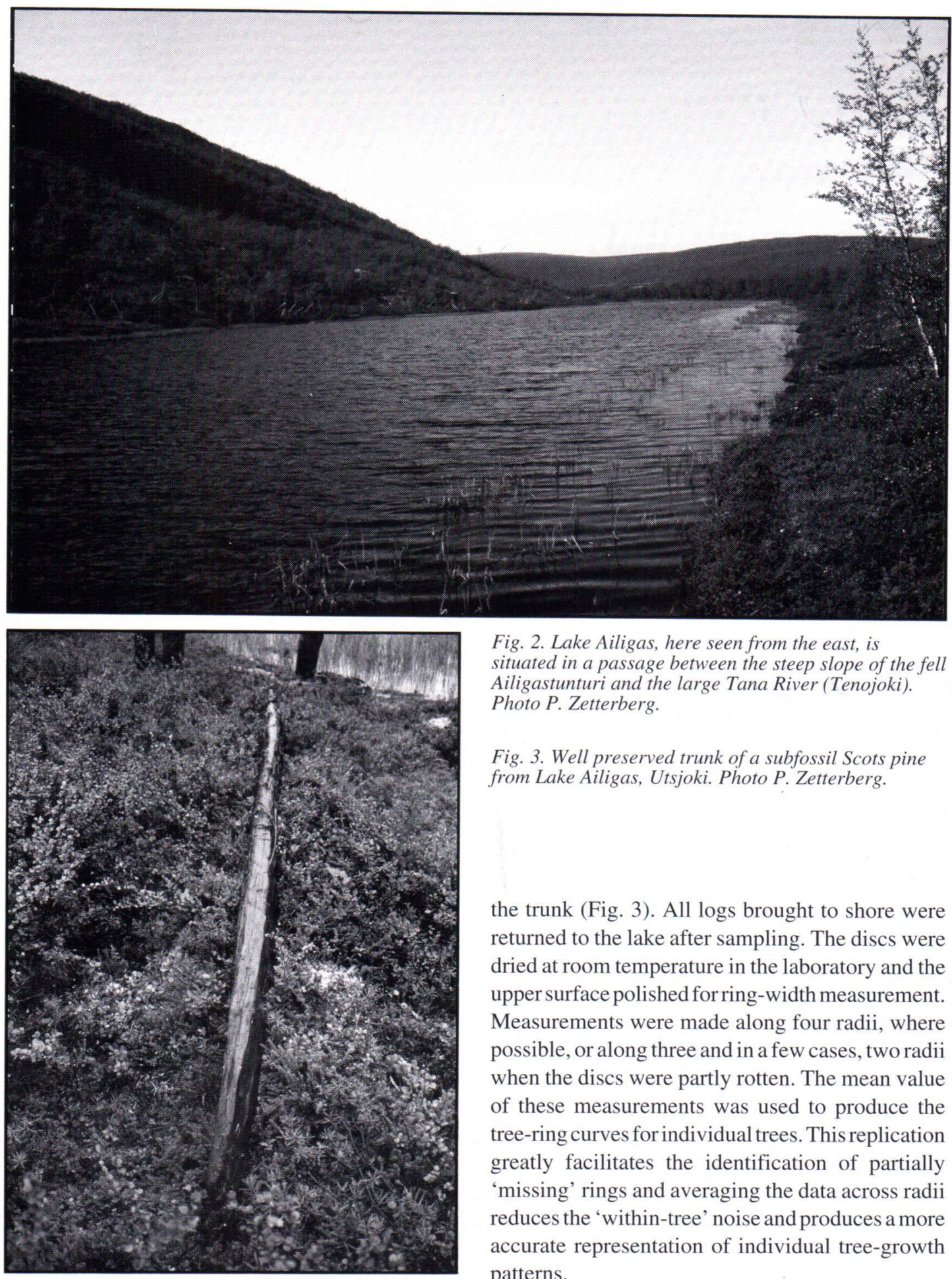

Fig. 2. Lake Ailigas, here seen from the east, is situated in a passage between the steep slope of the fell Ailigastunturi and the large Tana River (Tenojoki). Photo P. Zetterberg.

Fig. 3. Well preserved trunk of a subfossil Scots pine from Lake Ailigas, Utsjoki. Photo P. Zetterberg.

the trunk (Fig. 3). All logs brought to shore were returned to the lake after sampling. The discs were dried at room temperature in the laboratory and the upper surface polished for ring-width measurement. Measurements were made along four radii, where possible, or along three and in a few cases, two radii when the discs were partly rotten. The mean value of these measurements was used to produce the tree-ring curves for individual trees. This replication greatly facilitates the identification of partially 'missing' rings and averaging the data across radii reduces the 'within-tree' noise and produces a more accurate representation of individual tree-growth patterns. 
Standard dendrochronological methods were used in constructing the chronology (Fritts 1976). Measurements were made using Kutschenreiter equipment which was connected to the computer using the CATRAS programme (Aniol 1983) for data capture and handling. All datings of individual series achieved by statistical correlation between series were confirmed by visual inspection of the ring-width graphs.

\section{RESULTS}

\section{Dating of the pine samples}

A total of 90 samples collected from Lake Ailigas were successfully cross matched, which means that only a small portion of these trees remain undated. The most common reason for failure in dating was the occurrence of reaction wood in trees grown at the shore and tilted towards the lake. Difficulties also arise when the number of annual rings in a tree is less than 100 (e.g. Wigley et al. 1987).

The age distribution of the dated trees is shown in Fig. 4. The great majority of samples fall into the period starting just before the Christian era and ending in the 15th century, though 11 pines have been dated to earlier periods. Most of the trees lived during the first millennium after Christ. A smaller number are dated to the first half of the present millennium and only one tree died less than 500 years ago.

Because the Lake Ailigas trees do not cover the entire time span of the past 2000 years, additional tree-ring data were needed to connect the chronology to the present time: tree-ring samples taken from living pines and old wooden buildings in Utsjoki (Zetterberg 1990, Eronen et al. 1994a, Zetterberg, in press). These data overlap with the youngest part of the Lake Ailigas chronology. There are also many trees found in other small lakes in the Tana River valley which are dated to within the last 2000 years. Supporting data were also necessary to confirm the accuracy of the tree-ring curve for times around A.D. 900 and A.D. 1300, which are based on relatively little data in the Lake Ailigas series.

\section{The life spans of the subfossil trees and periods of germination and mortality}

The estimated life times of the individual subfossil pines are shown in Fig. 5. It is impossible to define the difference between number of measured rings and true cambial age accurately, but in most cases it is several tens of years. The real life time is always somewhat longer than the number of rings in the sample because the outermost rings have generally decayed. For this reason, we have added between 5 and 40 (average 19) years to the measured number in different samples to correct for the varying degrees of deterioration observed. Often, rings can be seen but are too distorted or decayed to attempt precise measurement. Also, because our samples are not always taken from the base of the stem, we have had to correct for the age of trees by the time they reached the sampling height. We have therefore also added between 10 and 50 years to the observed number of rings (average 28.5) to correct for this.

It can be seen from Fig. 5, that before A.D. 220, the tree age varies randomly between 60 and 300 years, but the more recent trees generally lived longer, reaching ages of 250 to near 400 years. In contrast, from 550 to 800 , trees are again younger, only 120 - 240 years. After 800 , the average life span again increases, with the oldest trees reaching almost 400 years again. Trees dying off in the 11th century are again younger and in the 12th century older, but the data are then becoming sparse in the younger periods of the Lake Ailigas time series.

Climatic stress, such as extreme cold conditions, influences the number of trees dying. Above-average warmth can increase the number starting their growth. Therefore, during periods of high inter-annual temperature variability (or some other climatic factor), greater numbers of trees are likely to die and others germinate than would be the case under more stable conditions (Karlén 1993, Kullman 1993). The variations in germination and dying off 
Years A.D.

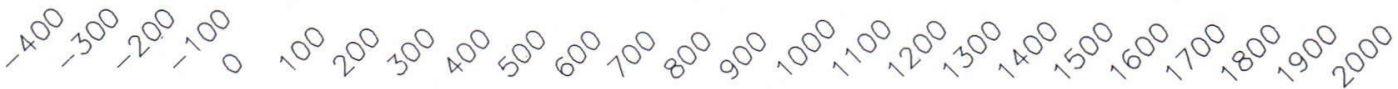

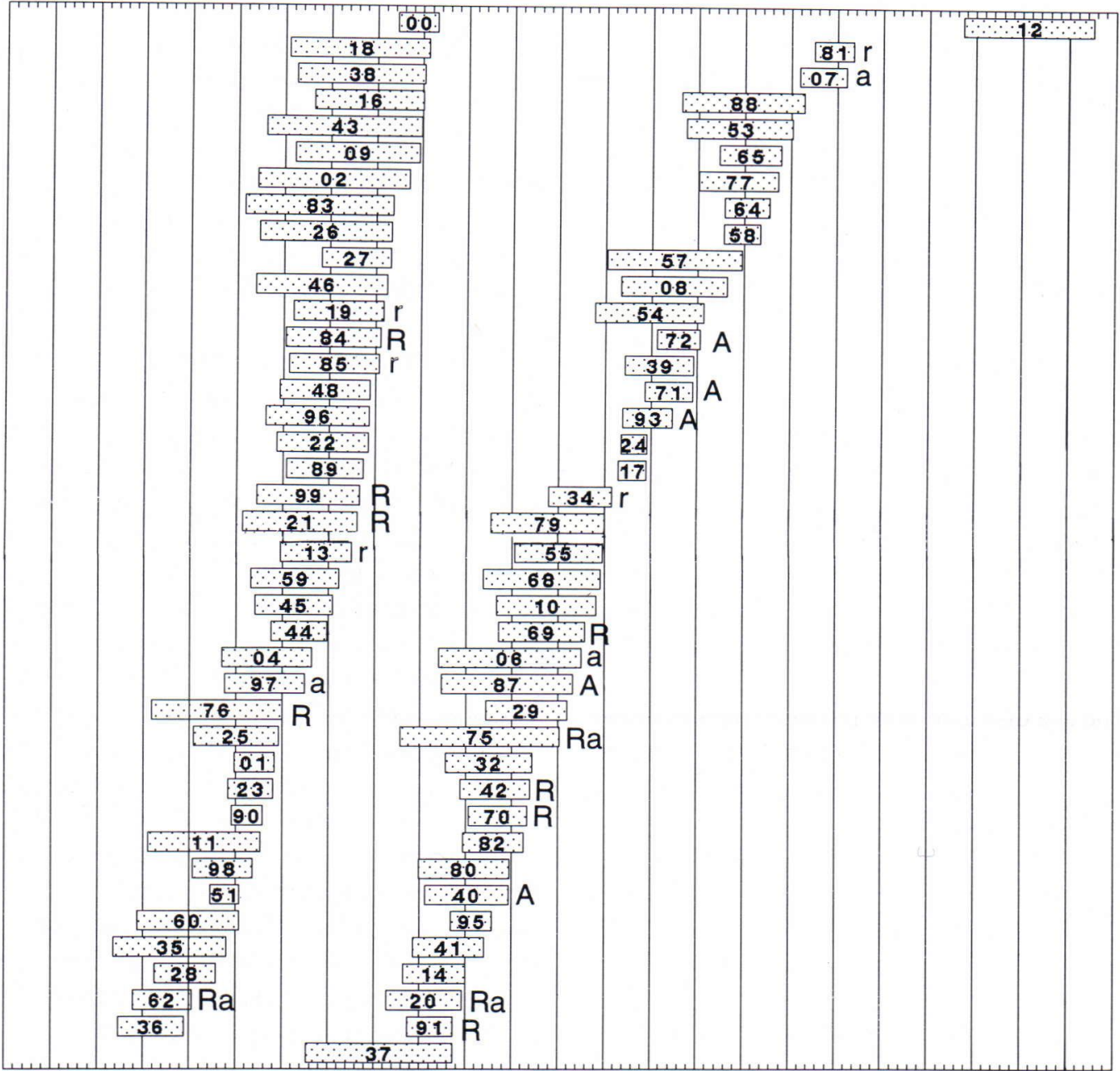

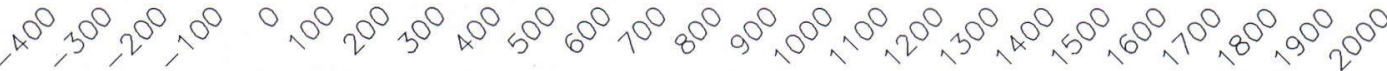

Fig. 4. Bar chart showing life span of subfossil pines from Lake Ailigas. Sample numbers are given inside the bars. Reaction wood on the last growth rings of the tree is indicated by an upper case $R$, a lower case $r$ indicates uncertain observation of reaction wood. Upper case A indicates a tree definitely felled by axe, while lower case a indicates a tree probably felled by axe. For details see text.

of trees can be used as a complementary source of information on past growing conditions (Zetterberg et al. in press). When interpreting Lake Ailigas data, we also have to take into account that Prehistoric Man has probably had at least a minor effect on the apparent mortality record of trees (see 
dying age

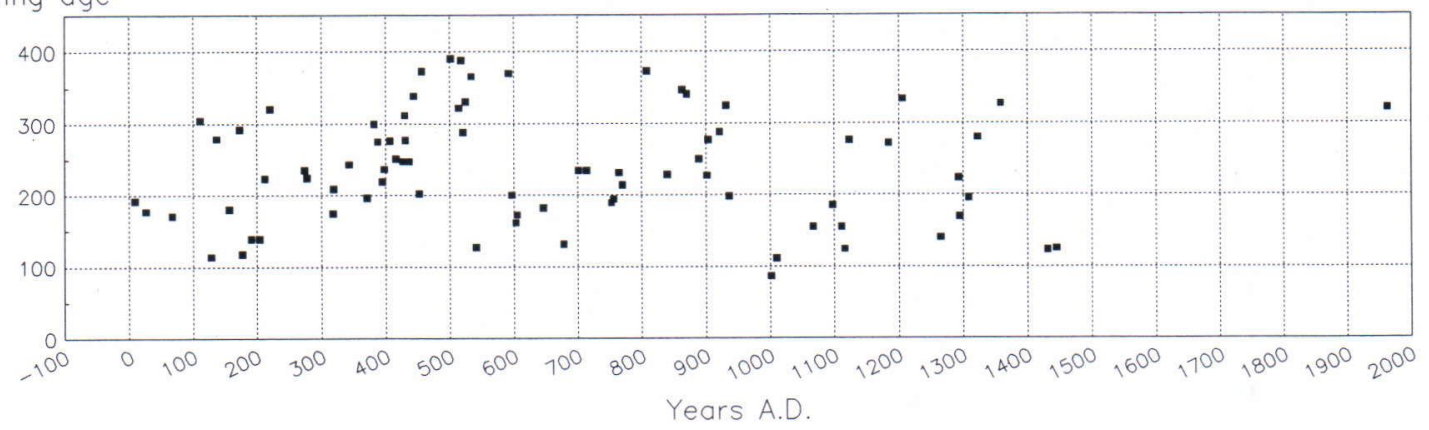

Fig. 5. The distribution of tree ages in the subfossil material at death. All the trees included in the Lake Ailigas chronology are plotted with regard to estimated age and year of death.

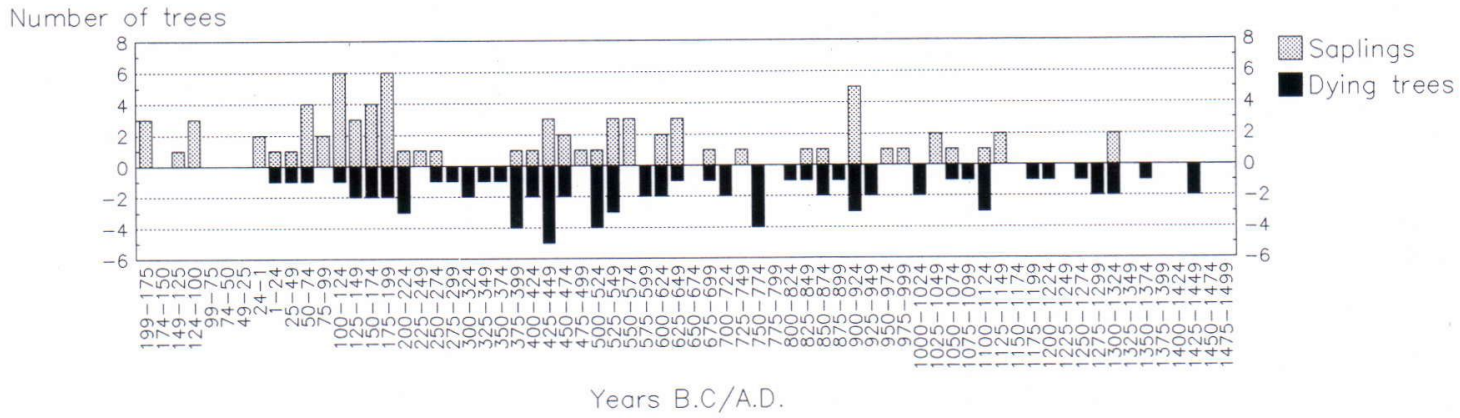

Fig. 6. Numbers of new pines which reached the sapling stage and pines that died during 25-year periods in the Lake Ailigas material. For details see text.

below).

The numbers of new pines which reached the sapling stage and the numbers of pines that died during each 25-year period are presented in Fig. 6. The most pronounced regeneration periods were at the beginning of the first millennium (particularly the second century), the period from 500 to 650 , and especially the first quarter of the tenth century. High mortality occurred at the end of the fourth century. Other notable periods of high tree mortality were $425-449,500-525$ and $750-774$.

\section{Ring-width variations}

The chronology constructed from ring-width data from the Lake Ailigas subfossil pines is shown in Fig. 7. No 'standardization' (i.e. correction to remove the age-related trends in individual series) was applied in chronology construction so as to maintain all possible long-timescale variation (e.g. see Cook and Briffa 1990). The variations in the master curve do not indicate the regional variations in ring-width exactly in the same way in all parts of the graph, because the data are not entirely homogeneous. Some parts of the curve are based on measurements made from old trees whereas tree rings of relative young trees form the majority of data in some other parts. The radial growth of younger trees is generally greater than that of old trees. This must be kept in mind, when making climatic interpretations using this kind of curve.

There are also variations in the chronology sample depth (i.e. replication) in different parts of the mean site curve. Because the section from 1200 - 1991 in Fig. 7 consists mainly of tree-rings sampled from 
Evidence on climatic variability and prehistoric human activities between 165 B.C. and A.D. $1400 \ldots 115$
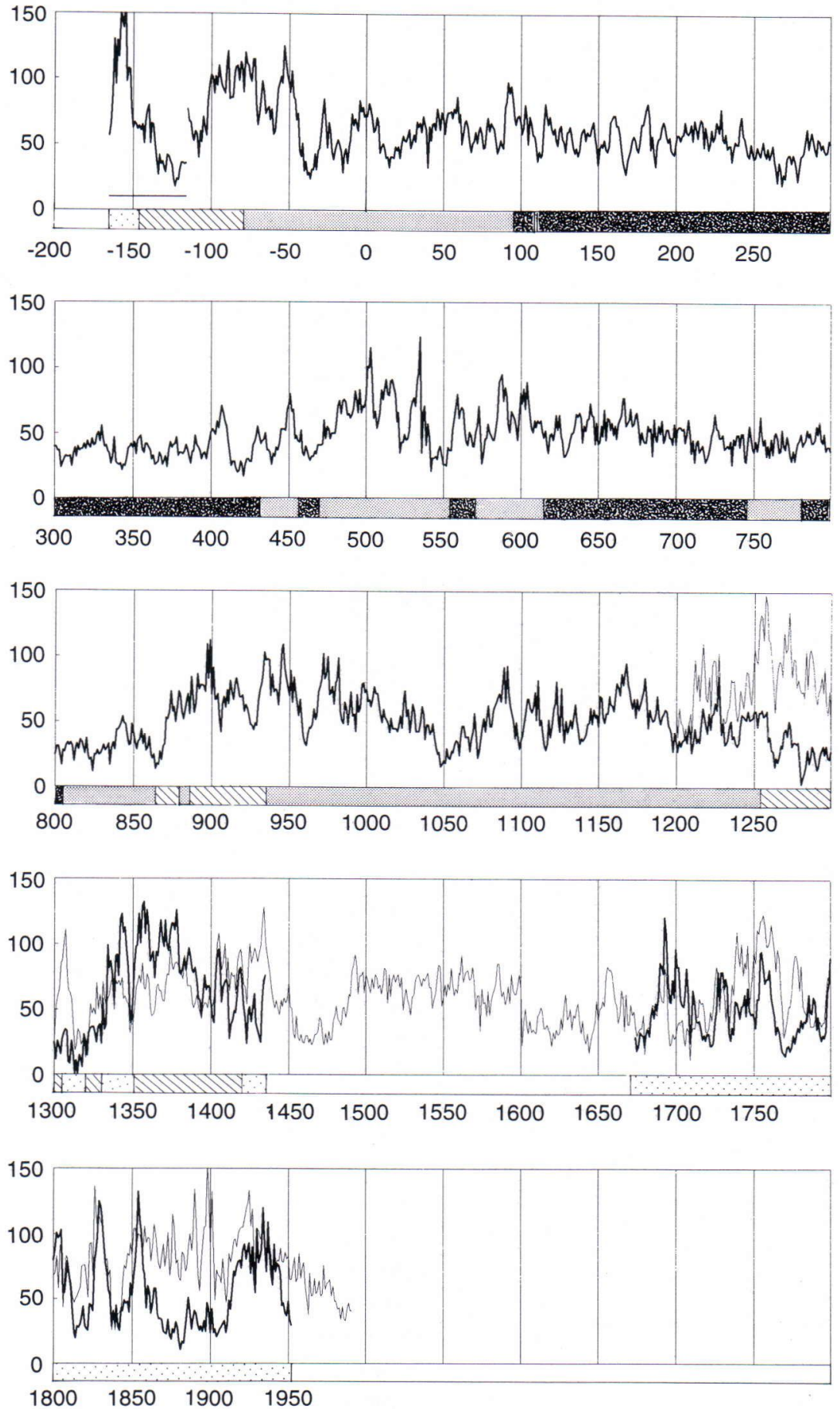

Fig. 7. Mean ring width chronology from the Lake Ailigas subfossil pines (wide line) with the mean ring width chronology of the Utsjoki-area for the period 1200-1991 A.D. (narrow line). The latter is obtained from living trees, logs from old buildings and subfossil pines from other sources than Lake Ailigas. The number of samples in the Lake Ailigas chronology is indicated by asterisks. In the underlined part of the curve the original values have been divided by two. 
wooden houses and living trees, the data represent potentially different environments than the Lake Ailigas pines. The living trees (sampled at Skalluvaara, Utsjoki) were growing on relatively dry ground whereas the original site characteristics of the trees used in the buildings are not known. There are no problems, however, in crossmatching these two data sets and both parts of the curve give information about past summer temperatures.

\section{Palaeoclimatic interpretation of the times of pine growth and subfossil ring-width variability}

Besides variations in ring-width, pine megafossils are also discussed here as they also provide important information on the quantity and quality of the source data. The period from 100 B.C. to A.D. 1250 is mostly represented by several trees. Sample depth is above 10 trees for half of the time and from five to nine trees during the remainder (Fig. 7). Between the late 800 s and the 930s the curve is based on only two to four trees. The data are also scarce from 1250 to the early 1400s.

There was probably a cool period between 130 and 120 B.C. because all pines living then indicate very poor growth. Warming began after 120 B.C. indicated by pronounced radial growth. Three new trees appeared in the record which might also indicate warmer conditions which lead to the germination of new seedlings. The beginning of the first millennium B.C. was also warm. The tree rings are relatively wide and no trees died during that period. The latter part of the same century was cooler. The summers 53 and 29 B.C. were warm, while those in 70, 60, 36 and 15 B.C. were cool. More favourable conditions prevailed again around the beginning of the Christian era.

The first century of the Christian era was generally warm, reaching peak value around A.D. 90. Eight new trees appeared and three trees died. A cold period occurred between A.D. 8 and 22 and there was again reduced growth in A.D. 40. Two trees, under 200 years old died during this period.

Relatively favourable conditions prevailed during the second century as indicated by the fairly constant tree growth. As many as 19 new trees in our data started their growth in this period. This was clearly the optimal growth period. Seven trees died after reaching ages between just over 100 years to over 300 years. There were also cool summers, first in $111-114$ and again 150, 168 and 187.

During the third century, radial growth shows a decreasing trend, suggesting a lowering of summer temperatures. Growth was especially weak between 263 and 279. Lowest values were in 265, 268 and 278. Only three new trees germinated. The fourth century was even less favourable for the growth of pine. The average width of rings remained below $0.5 \mathrm{~mm}$ each year. Only one new tree appeared and as many as eight died, four during the last quarter of the century. Many of the pines that appeared as seedlings in the second century died during this period after reaching ages of between $200-250$ years. Cold summers occurred in 304, 336, 339, 352,364 and 372 . The only warm summer was in 338.

The fifth century is characterized by marked variations in growth. The first decade, $400-410$, was clearly warmer than the overall average for fourth century, but it was followed by low temperatures in 412 - 426. A smaller peak in growth can be seen again between the late 420 s and 435 , but this was followed by a period of low growth with a minimum value in 439 A.D. Growth peaked in 449 - 453, but the early 460 s were cold. Growth then increased regularly until the early sixth century. Nine trees died by the end of the fifth century and seven new trees appeared. All of the dead trees were over 200 years and some were over 300 years old, two having germinated during the second century.

The sixth century data are also characterized by significant variations. During 530 - 540 the ring widths first reach high maximum values but then they fall sharply to a very low minimum. Unfavourable summers are indicated in 505, 522, 536, 539, 542, 575 and 598. Among these, the 536 A.D. drop in growth was extremely abrupt. This same growth decrease has been noted in northern Swedish pines, Irish oaks and other high-resolution 
data and it has been speculated that this may have been the result of some form of dust veil, though there is not, as yet, any evidence for a major volcanic eruption at this time (Baillie 1994). Warm years occurred in 503, 535, 537, 540 and 575 . Seven trees died, six of which were 300 - 400 years old. The oldest ones were the last pines remaining from the second century generation. Six new trees germinated.

The strong variations then subsided during the seventh century, indicating more stable and favourable climatic conditions. The most favourable growth period was in the beginning of the century, but during 627 - 632 summers were cool. Later, in 649 and 686 summers were warm. Six new trees appear in the data and four trees died. All had lived for less than 200 years.

The eight century was characterized by a decreasing trend in growth, in some respects resembling that of the fourth century. Growth was very weak in 712 and 736 whereas the years 725 and 745 show high growth. Only one new tree appeared while four died, all during the latter part of the century. Again these trees had lived only for about 200 years.

Probably the coldest summers of the entire period between 100 B.C. and A.D. 1250 occurred in the early and middle part of the ninth century. Pine ring widths were at their lowest in 800, 804, 812, 824, 835 and around 865 . Growth improved in the late ninth century, peaking in 897 to 899 . Five trees died and two trees germinated during this 100-year period. Two of the trees were over 200 and three over 300 years only at their death.

The 10th century was again more favourable. Average width was three times that during the early ninth century. Best growth occurred in 934, 945, 946 and 982 while growth was low in $906,938,956$ and 961 .

There were no strong oscillations in summer temperatures in the early 11 th century but there were following this. In the middle period, from A.D. 1044-1060 growth was exceptionally poor and minimum ring-width values occurred in 1048 to 1051 . Rings formed at this time were on average as narrow as those during the early and mid ninth century minima. After the cool phase growth increased for three decades and peak values were reached in 1089 and 1091 before poorer growth at the century. Summers were apparently cool in 1072 and 1090. Three new trees appeared and four trees died.

The temperature oscillations of roughly 10 years in length, which had started in the latter part of the previous century, continued during the first half of the 12 th century. Growth peaked in the 1160 s, with a maximum value in 1168 . The subsequent fall in temperatures was maintained until the beginning of the next century. At the end of the 12th century, average tree growth was only about half of that in the 1160s. Four trees died, two of them before the age of 150 , and three new trees appeared in the data.

The sample replication in these Lake Ailigas data is adequate only in the first half of the 13th century. The curve for the second half is based only on two trees. In the early 14th century is a short period represented by only one tree (Fig. 7). Early 13th century summers were mostly cool, but later tree growth apparently increases to a maximum in 1227. Growth was fairly low in 1210, 1229, 1263 and 1280 . Four trees died and no new trees appeared in our data in the 13th century.

The tree-ring curve, albeit based on a few data, indicates that the period from 1260 to 1320 was characterized by cool summers. The trees that grew after 900 did not live as long as those in earlier periods. It is difficult to interpret this observation in terms of climatic variations because we do not know the primary reason for this mortality. Some trees may have been felled by storms; some may have suffered from rising water levels in the lake due to increased humidity (cf. Hyvärinen and Alhonen 1994) and some may have become stressed by periods of strong temperature variability. Last, and perhaps most significantly, we must also consider the possible impact of man. We have evidence that many trees in this period were cut by axe (see below).

The data for the 14th century consist of only two pines. Both specimens indicate strong growth in the 
middle and late parts of the century, which were probably therefore relatively warm. Two trees died and the other two pines which started their growth in this century, died in early 15 th century. After that time there is a long gap in the Lake Ailigas subfossil data. The only tree representing the younger times started its growth in the late 17 th century and died in mid 20th century.

\section{DISCUSSION}

The reasons why pines have come to be preserved in Lake Ailigas

The pines recovered from Lake Ailigas represent only a small part of the population of trees that grew near and in the surroundings of the lake over a long period of time. There are four principal ways that trees come to be in a lake: 1) A storm fells living trees. 2) A tree dies 'naturally' after reaching an old age/or having been stressed by some environmental/ climatic factors. 3) A tree growing at the shore becomes more and more tilted towards the lake until the roots cannot hold it upright and the tree falls. The tilting can be brought about by changes in the shore, e.g. erosion or svamping due to a rise in water level. 4) The rise in water level can 'drown' trees by water logging of the soil so that the respiration of the roots is hindered. The dead tree then rots slowly at the base and finally falls into the lake.

The last two of these possibilities probably caused the majority of these trees to be found in Lake Ailigas. The trees produce 'reaction wood', i.e. the tree rings grow wider and more dense (compression wood) on that side of the trunk which has tilted towards the lake in order to compensate for the lean and in attempt to right the trunk. There are 12 subfossil trunks with reaction wood in their outermost tree-rings in our present data and five additional trees where the tree-ring pattern suggests reaction wood but it cannot be distinguished with absolute certainty. A long-lasting slow tilting leads to a curved shape of the trunk, but such trees are rare in our data, and it is therefore likely, that tilting happened rapidly and the trees fell quickly.

The tree-ring pattern cannot, unfortunately, reveal the causes of tilting. Many trees being tilted and then killed at the same period of time might suggest a rise in water level which softened or eroded the soil at the shore. In the Lake Ailigas data there are three certain and three possible observations of reaction wood in trees that died in the late fourth and early fifth century (Fig. 4). This could be interpreted as indicating a rise in water table occurring over several decades at that time. The relatively narrow tree-rings also indicate that the summers in the fourth century were generally cool. Reaction wood in four trees that died in the late sixth and first half of the eighth centuries might also indicate rising lake levels.

The role of storms in the death of lake margin pines is difficult to determine. Strong storms can blow down large numbers of trees at one site at the same time. In subfossil trees, however, several of the outermost rings have often decayed and the precise year of death can only be determined for a small minority of megafossils. It is impossible, therefore, to detect a sudden, simultaneous felling of several trees.

However, the short life span of the pines preserved as subfossils suggests that the main cause of tree death is not 'natural', i.e. old age. Tree ages in our data do not exhibit any clustering (Fig. 5). For example, the number of trees that reached ages between 100 and 199 years is approximately the same as the number dying between 200 and 299 years old.

An important contributory factor in the Lake Ailigas data is the impact of Prehistoric Man. The archaeological data show that the Saami (Lappish) people lived in the areas around Lake Ailigas since Neolithic times and evidence of their existence is especially plentiful during the Saami Iron Age which lasted until A.D. 1600 (Erä-Esko 1953, Rankama 1987, Purhonen and Ranta 1991). The Saami used trees as fuel and for building various structures, but the Prehistoric Saami were nomads who did not build permanent wooden houses. 


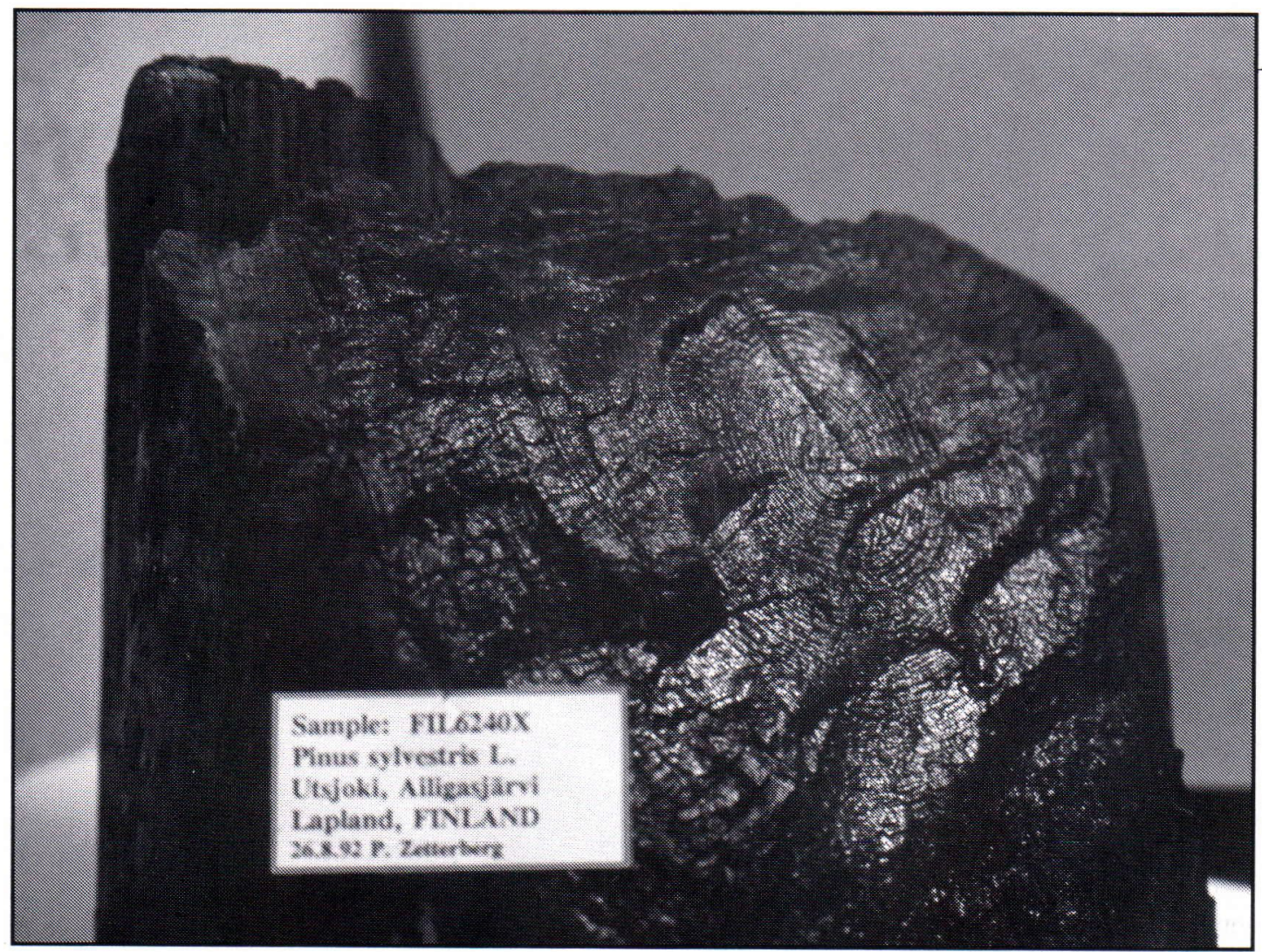

Fig. 8. Base of a subfossil pine tree cut by axe at the beginning of the eight century. Sample from Lake Ailigas, Utsjoki, northernmost Finland. Photo P. Zetterberg.

However, one specific use of timber is particularly significant as regards the Lake Ailigas data. The hunting of wild reindeer was an essential part of the subsistence of these people. Traditional hunting methods were used until the 19th century (Itkonen 1962). A long primitive fence ('hangas') was built from pines (and spruces further south). The trees were felled and placed on the ground in a row so that the lower part of the trunks were supported above the ground and the tree canopies formed a continuous barrier which reindeer could not cross (Appelgren 1881). These fences were often built in the shape of a wide funnel into which the reindeer were first chased. They were herded in towards the most narrow end where pits had been dug. The reindeer then fell into these traps and were killed (Itkonen
1962). Several trees showing clear evidence of axe marks (Fig. 8) were found among the subfossil pines from Lake Ailigas. The remaining branches on these trees show that they were not trimmed or shaped after cutting. The only possible explanation for this finding is that the trees are remnants of old 'hangas' fences and Lake Ailigas was thus an important hunting place in Prehistoric times. The hunting probably took place in the autumn time, when the lake was frozen and the large Tana River nearby was ice free and snow cover was still thin. The steep slope of fell Ailigastunturi blocked the passage on the other side of the lake (Fig. 2). It was probably easy to kill reindeers on the slippery ice of the lake (Eronen et al. 1994).

The subfossil trees are always decayed to some 
degree and have often been damaged by ice or waves hitting the wood against the stony lake shore. Sometimes marks caused by this natural process are difficult to distinguish from axe marks caused by Man. We have therefore separated the evidence for axe marks into two groups in Fig. 4: those that can positively be attributed to Man cutting trees and those that are less clear and cannot be identified as such with absolute certainty.

The oldest axe marks positively identified are on a tree with outmost tree rings dated to the end of seventh century. Allowing for some possible decay, the probable cutting date is the very early eighth century. Man was again cutting trees in the ninth century. Probable axe marks are found on three pines, but positively on only one. It appears that these pines died simultaneously, however, suggesting that they were all cut at the same time, shortly after A.D. 850. The most recently definitely identified axe marks fall in the early 12 th century. The tree-ring series of three cut pines end close to the boundary of 11 th and 12 th centuries. The probable felling time can be bracketed between the two first decades of the 12th century. One other pine may also belong to this group. This tree was cut by axe and the dendrochronological dating places its latest rings in late 11th century. It is, however, omitted from the data presented in Fig. 4, because its tree-ring pattern has many irregularities that preclude its use in the site chronology for Lake Ailigas.

Besides those discussed above, four other subfossil pines may have been cut by axe. Their dates cover a long period of time, with the youngest coming from the 14th century.

The Lake Ailigas data show convincingly that the Saami people used pines during several past centuries. Obviously, there was no shortage of fuel wood because the cut pines were left on the ice, where they sank when the ice melted in spring. The Saami traditionally also used mountain birch for their fires, but pines may have been abundant in that area during the times of cutting.

The continuous Lake Ailigas pine record comes to an end in the 15th century. It is difficult to say whether Man destroyed the local stands of pine or played only a minor role while other factors contributes to the general retreat from the area. At least the Saami did not destroy the pine forest completely around the lake, because most of the trees, including the most recent ones, do not have axe marks. The abundance of subfossil pines in the lake from earlier centuries could have been the results of pines being carried from the surrounding area for building the barrier on the lake ice. The Saami were not likely to have dragged trees from a distance, but it is possible that not all megafossils necessarily came from the immediate surroundings.

Some climatic contribution to the disappearance of pines from the shore of Lake Ailigas cannot be excluded, and it possibly reduced the regeneration of pines so much that occurrences of pines became scarce in the 15 th century.

\section{Subfossil pines restricted to recent millennia}

The majority of the 90 dated pines from Lake Ailigas lived during the past 2000 years. Only 11 trees are from distinctly earlier periods and even these are relatively recent, being not older than 3000 years. The age distribution is, therefore, different from the other lakes containing abundant subfossil pines in Finnish Lapland (Eronen and Zetterberg, in press).

The absence of mid-Holocene pine megafossils in Lake Ailigas does not indicate a regional absence of pine. Pine trunks from that period have been found elsewhere in the Tana River valley (Eronen et al. 1994b) and the pollen records show that pines were common in northern Lapland then (Hyvärinen 1975, 1976). A likely explanation for the absence of earlier pines is that conditions were unfavourable for the preservation of the wood. The lake may not have existed prior to ca. 3000 B.P. It may have formed during the late Holocene, when the humidity of climate increased (cf. Hyvärinen and Alhonen 1994) and it probably led to enhanced paludification. A small creek runs through Lake Ailigas and a blockage in its flow could have led to its formation. 
A stratigraphical study of the lake sediments could possible confirm this suggestion, but such study has not been undertaken.

\section{Climate interpretations and comparisons}

We have described how the temporal distribution of survival times is relatively even in our subfossil pine data. Some regular variation can be seen however. Fig. 5 shows that the age at death has constantly increased during the four periods: $300-500,600-950,1000-1200$ and 1250-1350. This indicates that there have been four main generations of pines, with individual pines gradually dying, one after another within each generation. Only relatively few pines began growth outside of these four main generations.

The sparsity of pine generations over almost 1000 years indicates that conditions were seldom favourable for flowering and maturation of pine seeds. It is known from modern forestry studies that the regeneration of pine in the forest-limit zone requires at least two consecutive summers warmer than the 'average' and this occurs, at present, probably only a few times in a century (Sirén 1961). The Lake Ailigas subfossil pines show that conditions were similarly harsh for the northern pines in the past.

Briffa et al. (1990, 1992) have published interpretations of long tree-ring records (both ring-width and density) based on an earlier published pine chronology for northern Sweden (Bartholin and Karlén 1983) from pines in the Lake Torneträsk area, northern Sweden. That record extends from A.D. 500 to the present, so while our record terminates in 1400 , it extends over 600 years earlier than the Swedish reconstruction. Lake Torneträsk chronology has recently been extended to A.D. 1 (Briffa 1994). The distance between these two records is about $350 \mathrm{~km}$. The Torneträsk reconstruction is based on 'standardized' tree-growth series in which the effect of tree age have been removed in the mean chronologies and the data have been formally calibrated to represent April-August seasonal mean temperatures. As stated earlier, we have avoided standardization of our data in order to prevent the potential loss of information on climatic trends. Thus the data may contain some sample-age-related bias in different periods. Also, because these data are not continuous to the present day, they are not formally calibrated in terms of modern temperature data. Much previous work with ring-width data in Fennoscandian locations (Hustich 1948, Mikola 1950, Briffa 1990, 1992, Lindholm et al. in press) indicates that our data will represent, to a large degree, variations in July and August temperatures. On this basis, comparison with the Torneträsk reconstructions suggests that, in general, summer temperatures are fairly similar over the entire area of northern Fennoscandia, though some differences can be seen in the detailed patterns in the different parts of the region.

In Northern Sweden, the period 500 to 700 is cool on average. The Lake Ailigas data, however, show a marked oscillation in summer temperatures, especially in the sixth century. The eighth century, especially the middle part, was warm at Torneträsk in contrast to Lake Ailigas where the ring-width and other data indicate cool conditions.

In both regions, several decades around 800 were cool. During the following 200 years, temperatures generally rose, on average, at Lake Torneträsk. Our data are largely in accordance with this. Both sets of data show an abnormally cold period around 865 , but favourable growing conditions during $940-955$ is evidenced only by the Lake Ailigas data.

The period 970-1120 was warm at Lake Torneträsk, but a cooling had already begun in 1100 which continued until 1150. The Lake Ailigas data strongly indicate a cool period, with very reduced tree growth in 1044-1060, which is not seen in the Torneträsk record.

Both data sets show temperatures falling in the late 11th century, and strongly oscillating in the same way during the 12th century. There are some more or less insignificant differences in the two records towards the younger part of the Finnish record, but in general, the variations are largely in agreement. 
In the latest Medieval times, the Lake Ailigas data are very sparse and detailed comparisons are not justified.

\section{CONCLUSIONS}

The subfossil pines collected from Lake Ailigas constitute valuable material for studying past climatic variability. The 79 trees which grew in this small area provide a valuable record of generations of trees struggling for existence in extreme conditions. The account given in this paper is a case study, which forms a good basis for regional correlations. Detailed descriptions of representative sites are necessary to allow us to distinguish between local tree growth variations and large scale variations which are mainly caused by climatic changes in the forest-limit zone.

The data on the regeneration and mortality of trees provide information about past climate at the limit of the distribution of pine. Suitable warm conditions, conducive to the regeneration of pine, occurs infrequently, in the Lake Ailigas data, suggesting that the number of such favourable periods has been only four during the last 1500 years. Unfavourable times for the growth of pine cannot be unequivocally shown from the megafossil data, because there are several possible reasons for the death of trees. Nevertheless, cold summers coupled with a general instability in climatic conditions may increase the stress on trees and thus lead to increased mortality.

The graph of pine radial growth variations between 165 B.C. and A.D. 1400 presented here is based on averaging 'unstandardized' raw ring-width measurement data. These data have not been formally calibrated against instrumental data. Nevertheless, much previous work has shown that this series likely contains much information on summer temperature changes. A brief comparison of these data with published temperature reconstructions from northern Sweden has shown that summer temperature change has often been similar over a wide area of northern Fennoscandia. Our data represent a forward extension of this information by ca. 600 years.

Careful examination of the Lake Ailigas trees, their locations and their dendrochronological dating has suggested that a rise in the water table and perhaps the formation of the lake was brought about by increased humidity over past 3000 years. The traces of axe blows in several pines bear witness to the hunting practices of the late Iron Age Saami population.

ACKNOWLEDGEMENTS: This research is funded by the Academy of Finland (Finnish Research Programme on Climate Change), the European Science Foundation (Project European Palaeoclimate and Man), and EC Environment Research Programme in Climatology and Natural Hazards contract EV5V-CT94-0500: Tree-ring evidence of climate change in Northern Eurasia during the last 2000 years.

\section{REFERENCES}

Aniol, R.W., 1983. Tree-ring analysis using CATRAS. Dendrochronologia 1, 45-53.

Aniol, R.W. and Eckstein, D., 1984. Dendroclimatological studies at the northern timberline. In: Mörner,
N.-A. and Karlén, W., (eds.) Climatic changes on a yearly to millennial basis., pp. 273-279. D. Reidel Publishing Company.

Appelgren, H. 1881. Muinaisjäännöksiä ja tarinoita Kemin kihlakunnan itäisissä osissa.Suomen muinaismuistoyhdistyksen aikakauskirja 5, 1-86. 
Baillie, M.G.L. 1994. Dendrochronology raises questions about the nature of the AD 536 dust-veil event. The Holocene 4, 212-217.

Bartholin, T.S. and Karlén, W. 1983. Dendrokronologi i Lapland. Dendrokronologiska sällskapet, meddelande 5, 3-16.

Briffa, K.R. 1994. Mid and late Holocene climate change: evidence from tree growth in northern Fennoscandia. In: Funnell, B.M and Kay, R.L.F. (eds.) Palaeoclimate of the last glacial/interglacial cycle. Special Publication of the NERC Earth Sciences Directorate 94/2, 61-65.

Briffa, K.R., Bartholin, T.S., Eckstein, D., Jones, P.D., Karlén, W., Schweingruber, F.H. and Zetterberg, P. 1990. A 1400-year tree-ring record of summer temperatures in Fennoscandia. Nature 346, 434-439.

Briffa, K.R., Bartholin, T.S., Eckstein, D., Schweingruber, F.H., Karlén, W., Zetterberg, P. and Eronen, M., 1992. Fennoscandian summers from AD 500: temperature changes on short and long timescales. Climate Dynamics 7, 111-119.

Briffa, K.R., Jones, P.D. and Schweingruber, F.H., 1988. Summer temperature patterns over Europe: a reconstruction from 1750 A.D. based on maximum latewood density indices of conifers. Quaternary Research 30, 36-52.

Cook, E.R. and Briffa, K.R. 1990. A comparison of some tree-ring standardization methods. In: Cook, E.R. and Kairiukstis, L. (eds.) Methods of dendrochronology. Applications in the environmental sciences. Kluwer/ IIASA, Dordrecht, pp. 104-123.

Erä-Esko, A., 1953. Tutkimusraportti Guatniljärven kaivauksista. Museovirasto, Arkeologian osasto, topografinen osasto.

Eronen, M., 1979. The retreat of pine forest in Finnish Lapland since the Holocene climatic optimum: a general discussion with radiocarbon evidence. Fennia 157:2, 93-114.

Eronen, M. and Huttunen, P., 1987. Radiocarbon-dated subfossil pines from Finnish Lapland. Geografiska Annaler 69A(2), 297-304.

Eronen, M. and Zetterberg, P., 1992. Dendrochronology and climatic history in the subarctic area of Fennoscandia. In: Kanninen, M. and Anttila, P., (eds.) The Finnish Research Programme on Climate Change, Progress Report. Publications of the Academy of Finland 3/92, 13-18.

Eronen, $M$. and Zetterberg, $P$., in press. Expanding megafossil data on Holocene changes at the polar/ alpine pine limit in northern Fennoscandia. Paläoklimaforschung - Palaeoclimate Research 17.

Eronen, M., Zetterberg, P. and Lindholm, M., 1994a. Climate history from tree rings in the subarctic area of Fennoscandia. In: Kanninen, M. and Heikinheimo,
P., (eds.) The Finnish Research Programme on Climate Change, Second Progress Report. Publications of the Academy of Finland 1/94, 13-19.

Eronen, M., Zetterberg, P. and Okkonen, J., 1994b. Kirveen ja vaakanävertäjän (Tomicus minor, Hart.) jälkiä Lapin subfossiilisissa männyissä (Abstract: Axe marks and traces of a bark beetle (Tomicus minor, Hart.) in subfossil pines from Finnish Lapland). Terra 106, 238-248.

Fritts, H.C., 1976. Tree-rings and climate. Academic Press, London, $567 \mathrm{p}$.

Hustich, I., 1948. The Scotch pine in northernmost Finland and its dependence on the climate in the last decades. Acta Botanica Fennica 42, 1-75.

Hyvärinen, H., 1975. Absolute and relative pollen diagrams from northernmost Fennoscandia. Fennia 142(1), $1-23$.

Hyvärinen, H., 1976. Flandrian pollen deposition rates and tree-line history in northern Fennoscandia. Boreas $5,163-175$.

Hyvärinen, H. and Alhonen, P., 1994. Holocene lakelevel changes in the Fennoscandian tree-line region, western Finnish Lapland: diatom and cladoceran evidence. Holocene 4, 251-258.

Itkonen, T., 1962. Inarin Suomea viisi vuosikymmentä sitten. Virittäjä 57, 110-119.

Karlén, W., 1993. Glaciological, sedimentological and palaeobotanical data indicating Holocene climatic change in northern Fennoscandia. Paläoklimaforschung - Palaeoclimate Research 9, 69-83.

Kullman, L., 1993. Dynamism of the altitudinal margin of the boreal forest in Sweden. Paläoklimaforschung Palaeoclimate Research 9, 41-55.

Lindholm, M., Eronen, M., Meriläinen, J. and Zetterberg, $P$., in press. Climatic calibration of tree-ring width variations in forestlimit pines (Pinus sylvestris L.) in northern Finnish Lapland. Paläoklimaforschung - Palaeoclimate Research 17.

Mikola, P., 1950. Puiden kasvun vaihteluista ja niiden merkityksestä kasvututkimuksissa. (Summary: On variations in tree growth and their significance to growth studies). Communicationes Instituti Forestalis Fenniae 38:5, 1-131.

Purhonen, P. \& Ranta, H. (eds.), 1991. Arkeologia Suomessa 1986-1987, 195 pp,Vammala.

Rankama, T., 1987. Tutkimusraportti Onnelan kaivauksista. Museovirasto, Arkeologianosasto, topografinen osasto.

Sirén, G., 1961. Skogsgränstallen som indikator för klimatfluktuationerna i norra Fennoskandien under historisk tid. Communicationes Instituti Forestalis Fenniae 54:2, 3-65.

Wigley, T.M.L., Jones, P.D. and Briffa, K.R., 1987. 
Cross-dating methods in dendrochronology. Journal of Archaeological Science 14, 51-64.

Zetterberg, P., 1987. Site chronologies from eastern

Finland and Soviet Karelia. Annales Academiae Scientiarum Fennicae, AIII 145, 49-55.

Zetterberg, $P$., 1990. Lapin mäntyjen dendrokronologiaa. In: Holopainen, I.J. and Simola, H. (eds.) Ruijan retki 1989. University of Joensuu, pp. 93-99, Joensuu.

Zetterberg, $P$., in press. Dendrochronological dating in Finland. In: Jungner, H. \& Carpelan, C. (eds.) Time and Environment. Acts of the Symposium held at Helsinki, October 1990. Journal of the European
Study Group on Physical, Chemical, Mathematical and Biological Techniques Applied to Archaeology $36,6 \mathrm{p}$.

Zetterberg, P. and Eronen, M., 1994. Subfossiilisten mäntyjen dendrokronologiset tutkimukset Lapin metsänrajavyöhykkeessä (Summary: Dendrochronological studies on subfossil forest-limit pines in Lapland). Acta Universitatis Ouluensis A 251, 97-105. Zetterberg, P., Eronen, M. and Lindholm, M., in press. The mid-Holocene climatic change around 3800 B.C: tree-ring evidence from northern Fennoscandia. Paläoklimaforschung-Palaeoclimate Research 17. 